\title{
The Second Deep Ice Coring Project at Dome Fuji, Antarctica
}

by Hideaki Motoyama

\section{Introduction}

Throughout the history of the polar icecaps, dust and aerosols have been transported through the atmosphere to the poles, to be preserved within the annually freezing ice of the growing ice shields. Therefore, the Antarctic ice sheet is a "time capsule" for environmental data, containing information of ancient periods of Earth's history. To unravel this history and decode cycles in glaciations and global change is among the major goals of the Dome Fuji Ice Coring Project.

With an elevation of $3810 \mathrm{~m}$, Dome Fuji (39²' $42^{\prime}$, $\left.77^{\circ} 19^{\prime} \mathrm{S}\right)$ is the second highest dome summit on the Antarctic ice sheet and might be one of the locations holding the oldest ice in
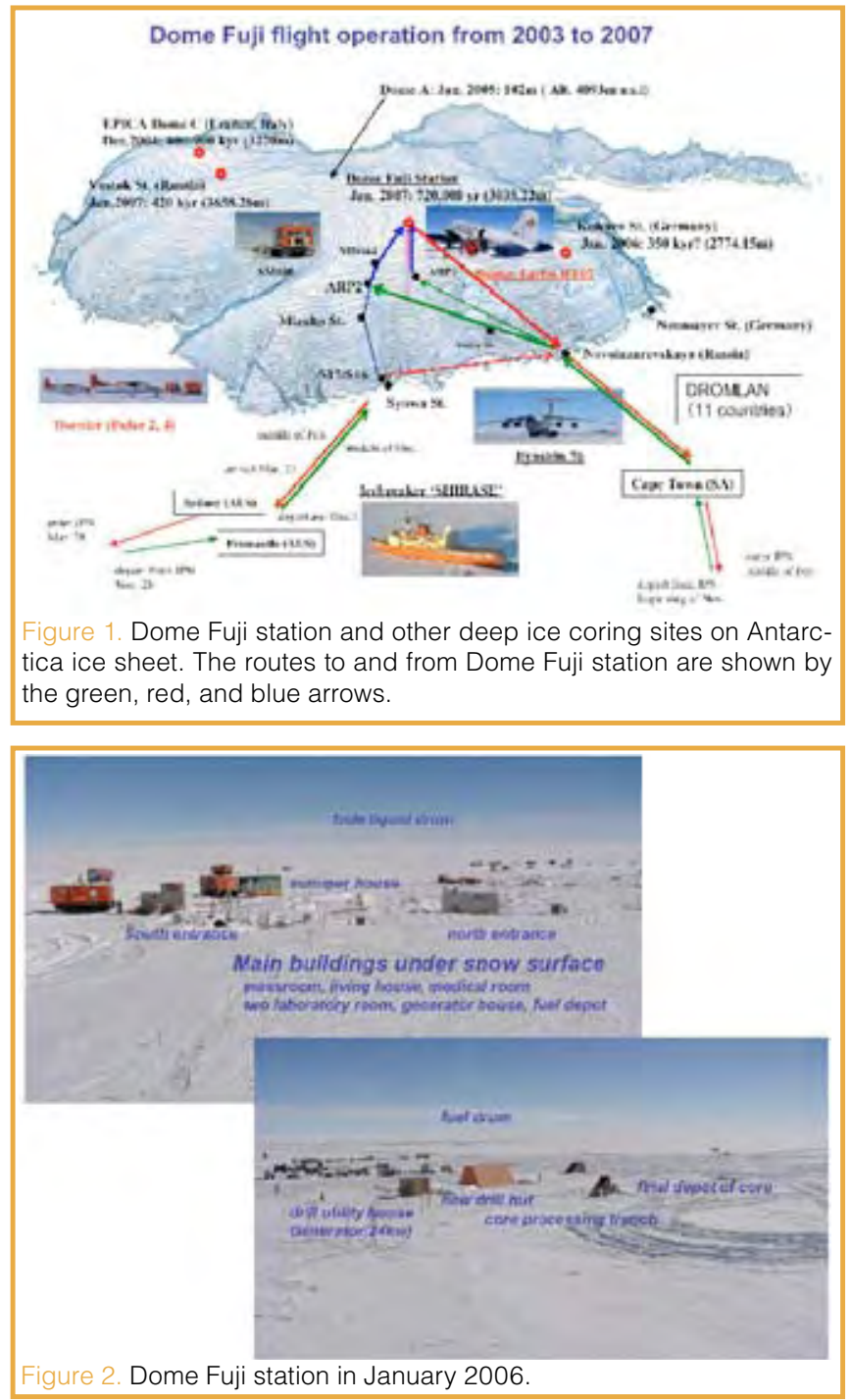

Antarctica. The base of the ice underneath Dome Fuji is estimated to have formed at the beginning of the glacial cycle in the Quaternary era. Analysis of this ice can shed light on the mechanism of Quaternary glacial cycles. The second deep ice coring project at Dome Fuji, Antarctica reached a depth of $3028.52 \mathrm{~m}$ ( $3810 \mathrm{~m}$ above sea level) during the austral summer season in 2005/2006 (Figs. 1 and 2). The recovered ice cores contain records of global environmental changes going back about 720,000 years. During the recent 2006/2007 season the Japanese Antarctic Research Expedition (JARE) team finally reached a depth of $3035.22 \mathrm{~m}$ at the Dome Fuji station on 26 January 2007.

\section{First Deep Ice Core Drilling at Dome Fuji}

In December 1996, during the first deep ice core drilling campaign at Dome Fuji, the 37th JARE team had succeeded coring the ice to a depth of $2503 \mathrm{~m}$. Due to a shortage of antifreeze supply, the drilling team temporarily stopped drilling and waited to receive supplies to arrive with the next drilling team (JARE 38). However, while reaming and chip recovery were repeated using the ice core drill in order to keep the hole open, the drill became stuck at the end of December at a depth of approximately $2300 \mathrm{~m}$. The subsequent 39th and 40th JARE teams attempted to recover the drill by injecting high density liquid (hydrochlorofluorocarbon) $200 \mathrm{~m}$ below the surface of the ice sheet ( $100 \mathrm{~m}$ below the liquid level), but this attempt failed, and the borehole had to be abandoned.

A second deep ice coring project was commenced at Dome Fuji during 2001. It was decided to draw on new drilling technology developments and to establish a new borehole about $43 \mathrm{~m}$ north of the abandoned one with the aim of full penetration to bedrock. A pilot hole was drilled to a depth of $122 \mathrm{~m}$, and a casing was installed by the 42 nd JARE wintering team in 2001. In 2002 the 43rd JARE team constructed a new deep ice core drilling house, updated the station equipment, and began repairing the logistic equipment. The 44th Dome Fuji wintering team completed and prepared the new deep ice core drilling system in 2003-a completely new deep ice core drill of $4.0 \mathrm{~m}$ core barrel length. It subsequently proved to be of true world class quality, when it was able to recover $3.84 \mathrm{~m}$ of the ice core in each operation with almost no unexpected difficulties caused by ice chip clogging. Due to logistical considerations, only summer operations were performed. 


\section{Deep Ice Core Drilling Technology}

The deep ice coring drill used during this project is an electro-mechanical liquid-filled type. A schematic diagram and photos are shown in Fig. 3, and the main specifications of the drills used at Dome Fuji are summarized in Table 1. The ice drill consists of a core barrel, a chip chamber, a pressure tight section, and an anti-torque section (Takahashi et al., 2001). Three cutters are attached to cut an ice core of $94 \mathrm{~mm}$ diameter, leaving a borehole of $135 \mathrm{~mm}$ diameter. To prevent borehole closure during drilling, the borehole is filled with an anti-freezing fluid, n-butyl acetate. Its density is about equal to the ice, and the viscosity at temperatures below $-50^{\circ} \mathrm{C}$ is low. Since the second deep ice coring project drilled only during the austral summer season, the design of the drill could be improved to increase the productivity under this premise. The equipment was able to penetrate up to $3.84 \mathrm{~m}$ for each core, as opposed to the $2.3 \mathrm{~m}$ cored during the first deep ice coring project. Effective transportation and storage of the cutting chips generated by the drill turned out to be one of the biggest problems. Technicians experimented with various pumps to solve this problem, and finally an archimedean screw pump was used, which is operated by rotating a core barrel (Fig. 3C) through a spiral spring located within a double tube. A propeller-like booster attached to the driving shaft of the core barrel provides momentum for the transportation of the borehole liquid and cutting chips to a chip chamber (Fig. 3B).

A special pipe perforated with many small holes was manufactured for storing the cutting chips, while the liquid could easily pass through the perforations (Fig. 3A). However, the cutting chips create a countercurrent in the chip chamber during drill ascent, leading to leakage of the chips from the chip chamber. A current prevention system, including a new check valve and direct current (DC) drill motor, was adopted to prevent this from happening.

\section{Difficulties and Progress}

In the first season, 2003/2004, the final drilling depth achieved was $362 \mathrm{~m}$ despite significant logistics problems with weather and transportation of equipment. However, with the considerable experience gained in the 2003/2004 season, it was possible to drill ice cores smoothly during the summer season of 2004/2005. The hole was deepened by approximately $1500 \mathrm{~m}$, reaching a total drilling depth of $1850.35 \mathrm{~m}$.

To reach the bedrock of Antarctica under the ice sheet, 1200 meters had to be drilled in the last projected summer season 2005/2006. Hence, it was necessary to arrive at the Dome Fuji station at the earliest possibility. The team arrived at the station on 17 November 2005. The drilling resulted in a record high $133 \mathrm{~m}$ of drill core per week without encountering problems, and a drilling depth of $3000 \mathrm{~m}$ was achieved on 12 January 2006. Through most drilling runs, a 3.7-m ice core of excellent quality was obtained. When the drilling depth exceeded $3000 \mathrm{~m}$ near the bedrock, the ice temperature was close to the pressure melting point. The cutting chips immediately froze to become ice, which made chip transportation within the corer very difficult. At this depth, nearly four hours were required for each single ice coring operation, with performance rapidly decreasing. Finally, only ten centimeters of the ice core could be drilled on average with each core. Because it had been expected that the "warm" ice would cause problems, the normal drill was replaced with a special short teflon-coated drill in an attempt to determine the most suitable drilling method. The final drilling depth was $3028.52 \mathrm{~m}$ on 23 January 2006, when drilling had to stop to provide sufficient time for demobilization of the operation and crew.

Ultimately, to reach the bedrock, the deep ice core drilling was extended for another year. In the fourth drilling season, 2006/2007, the total drilling period was 39 days. The total drilling length was $6.70 \mathrm{~m}$, and the final drilling depth reached was $3035.22 \mathrm{~m}$. The average core length was approximately $10 \mathrm{~cm}$, which was half the length expected. The overall progress of deep ice core drilling throughout the seasons 2003 to 2007 is summarized in Fig. 4.

When a drilling depth of $3034.34 \mathrm{~m}$ was reached, a special type of small ice pieces appeared to be abundant in the chip chamber and in the frozen water chip accumulating on the 


\begin{tabular}{|c|c|c|c|}
\hline Item & Phase 1 Model & Phase 2 Model & Phase 2 Model (for warm ice) \\
\hline Type & Electro-Mechanical Drill & Same as Phase 1 & no change \\
\hline Core $\varnothing \mathbf{x L}$ & $94 \mathrm{~mm} \times 2,200 \mathrm{~mm}$ & $94 \mathrm{~mm} \times 3,840 \mathrm{~mm}$ & $94 \mathrm{~mm} \times 2,000 \mathrm{~mm}$ \\
\hline Cutting Speed & $15-20 \mathrm{~cm} / \mathrm{min}$ & Same as Phase 1 & no change \\
\hline Static Pressure & $30 \mathrm{MPa}$ & Same as Phase 1 & no change \\
\hline Drill Size $Ø \mathbf{x L}$ & $122 \mathrm{~mm} \times 8,593 \mathrm{~mm}$ & $122 \mathrm{~mm} \times 12,200 \mathrm{~mm}$ & $122 \mathrm{~mm} \times 8,106 \mathrm{~mm}$ \\
\hline Cutter & $3 \times$ Block Type & Same as Phase 1 & Special \\
\hline Core Barrel $\varnothing \mathbf{x L}$ & $101.6 \mathrm{~mm} \times 2,321 \mathrm{~mm}$ & $101.6 \mathrm{~mm} \times 4,000 \mathrm{~mm}$ & $101.6 \mathrm{~mm} \times 2,256 \mathrm{~mm}$ \\
\hline $\begin{array}{l}\text { Chip Chamber } \\
\varnothing x L \text { \& Density }\end{array}$ & $\begin{array}{l}112 \mathrm{~mm} \times 3,260 \mathrm{~mm} \\
\rho=500 \mathrm{~kg} \mathrm{~m}^{-3}\end{array}$ & $\begin{array}{l}112 \mathrm{~mm} \times 5,533 \mathrm{~mm} \\
\rho=550 \mathrm{~kg} \mathrm{~m}^{-3} \\
\text { Hole: } 1.2 \mathrm{~mm} \varnothing \times 45,000\end{array}$ & $\begin{array}{l}112 \mathrm{~mm} \times 3,160 \mathrm{~mm} \\
\rho=550 \mathrm{~kg} \mathrm{~m}^{-3} \\
\text { Hole: } 1.2 \mathrm{~mm} \varnothing\end{array}$ \\
\hline Chip Pump & $\begin{array}{l}\text { Archimedean Pump \& } \\
1 \text { Turn Screw Booster }\end{array}$ & $\begin{array}{l}\text { Archimedean Pump \& } 1 \text { or } \\
0.75 \text { Turn Screw Booster x 2-3 }\end{array}$ & $\begin{array}{l}\text { Archimedean Pump \& } 1 \text { or } \\
0.75 \text { Turn Screw Booster } x 2\end{array}$ \\
\hline Motor Output Power & $\begin{array}{l}\text { AC Brushless Motor } 600 \mathrm{~W} \\
\text { for } 15 \mathrm{~min} \text { at } 12,000 \mathrm{rpm}\end{array}$ & $\begin{array}{l}\text { DC Permanent Magnet Motor } \\
\text { with Brushes, } 600 \mathrm{~W} \text { for } 15 \mathrm{~min} \text {. } \\
\text { at } 4,000 \mathrm{rpm} .\end{array}$ & no change \\
\hline $\begin{array}{l}\text { Reduction Gear } \\
\text { Type \& Ratio }\end{array}$ & $\begin{array}{l}4 \text { Stage Planetart } \\
\text { Gear } 1 / 170\end{array}$ & $\begin{array}{l}\text { Harmonic Drive Type: CSF17, } \\
1 / 100,1 / 80(, 1 / 50)\end{array}$ & no change \\
\hline Electronics & $\begin{array}{l}\text { Monitoring Computer } \\
\text { (10 Parameters) }\end{array}$ & Same as Phase 1 (version 2) & no change \\
\hline $\begin{array}{l}\text { Pressure Chamber } \\
\text { ØLL \& Pressure }\end{array}$ & $\begin{array}{l}122 \mathrm{~mm} \times 1,700 \mathrm{~mm} \\
30 \mathrm{MPa}\end{array}$ & Same as Phase 1 & no change \\
\hline Anti-Torque & $3 \times$ Leaf Spring & Same as Phase 1 & no change \\
\hline Cable ØxL & $\begin{array}{l}\text { 7-H-314K, } \\
7.72 \mathrm{~mm} \times 3,500 \mathrm{~m}\end{array}$ & Same as Phase 1 & no change \\
\hline Hole Liquid & n- butyl acetate & Same as Phase 1 & no change \\
\hline Special Items & & $\begin{array}{l}\text { 1. System to Prevent Adverse } \\
\text { Current of Chips } \\
\text { 2. Super Banger }\end{array}$ & $\begin{array}{l}\text { 1. Special Cutter Mount } \\
\text { 2. Teflon Coated Drive Shaft, } \\
\text { Screw Booster, Cutter, Core } \\
\text { Catcher, Outer Tube, Core } \\
\text { Barrel }\end{array}$ \\
\hline
\end{tabular}

gases were trapped as air bubbles in the ice sheet and will be analyzed.

The ice cores recovered from the Dome Fuji station confirmed that the history of global environmental changes could be continuously recorded from 720,000 years in the past. More analysis will be conducted to clarify the Earth's climate, microorganisms present in ice, and space climate. Currently, ice core studies are being conducted in cooperation with the National Institute of Polar Research in Tokyo, Japan, other universities, and other institutes.

For more information about the Dome Fuji Deep Ice Coring Project see the Web link below.

\section{References}

Fujii, Y., Azuma, N., Tanaka, Y., Nakayama, M., Kameda, T., Shinbori, K., Katagiri, K., Fujita, S., Takahashi, A., Kawada, K.,

ice core (Fig. 5). The crystal structure of these strange ice pieces differed from that of the cutting ice chips. The conclusion was that water beneath the ice sheet had probably leaked into the borehole and had frozen in the drill. In addition, the ice core was found to be contaminated with small rocks. Hence, since liquid water existed near the bedrock, the drilling machine was covered with ice when it was positioned in the ground to drill through the ice sheet, which had a temperature of $-55^{\circ} \mathrm{C}$ or lower. The shape of the ice underneath the drill resembled frozen drops of water. Drilling was carefully continued for the next days, and finally, the last ice core was recovered topped with mysterious white frozen water from a depth of $3035.22 \mathrm{~m}$ below the surface.

\section{Preliminary Analysis of the Ice Core}

The oxygen isotope ratio of the ice core was measured to determine its age. This ratio fluctuates depending on the paleotemperatures, and it can be used to study the past glacial-interglacial cycles in great detail. The ages of the ice cores were estimated by comparing the determined age with the Dome $\mathrm{C}$ ice core data from the European Project for Ice Coring in Antarctica (EPICA). As a result, the deepest ice cores at Dome Fuji were estimated to be approximately 720,000 years old. Traces of atmospheric

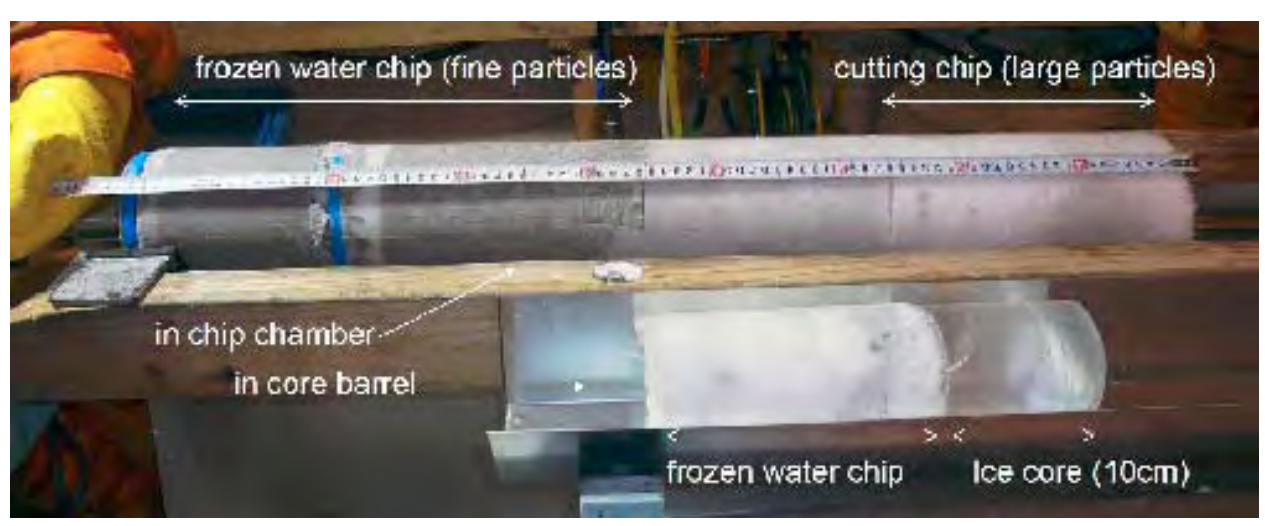

Cutting chips of ice core and a lot of frozen water chips. Motoyama, H., Narita, H., Kamiyama, K., Furukawa, T., Takahashi, S., Shoji, H., Enomoto, H., Saitoh, T., Miyahara, M., Naruse, R., Hondoh, T., Shiraiwa, T., Yokoyama, K., Ageta, Y., Saito, T., and Watanabe, O., 2001. Deep ice core drilling to $2503 \mathrm{~m}$ depth at Dome Fuji, Antarctica. Natl. Inst. Polar Res., Spec. Issue, 56:103-116.

Takahashi, A., Fujii, Y., Azuma, N., Motoyama, H., Shinbori, K., Tanaka, Y., Watanabe, O., Narita, H., Nakayama, Y., Kameda, T., Fujita, S., Furukawa, T., Takata, M., and Miyahara, M., 2001. Improvements to the JARE deep ice core drill. Natl. Inst. Polar Res., Spec. Issue, 56:117-125.

\section{Author}

Hideaki Motoyama, National Institute of Polar Research, Kaga 1-9-10, Itabashi-ku, Tokyo 173-8515, Japan, email: motoyama@pmg.nipr.ac.jp.

\section{Related Web Link}

http://polaris.nipr.ac.jp/ domef/home/eng/index-e.html 